\title{
Quality Of Life Among Leprosy Patients
}

\section{Nesma Mohamed FaheemAbd EL-Rahman', Dr. Gehad Mohamed Abou EL- Matty $^{2}$,}

\author{
Dr. Naglaa Ibrahim mohamedGida ${ }^{3}$, Dr. Abdel El-Nasser Ramadan ELkholy ${ }^{4}$ \\ Professor of Family and Community Health Nursing, Faculty of Nursing, Port said \\ University $^{2}$, Assistant professor .of Family and Community Health Nursing ,Faculty of \\ Nursing, Port said University ${ }^{3}$, M.D. Dermatology and Venereology, El Mansoura \\ Dermatology and Leprosy Hospital ${ }^{4}$
}

\begin{abstract}
Background: Leprosy is caused by mycobacterium leprae and spread among those living in poverty. stigma has been associated with leprosy. Aim: Assess quality of life among leprosy patient. Subjects and method: .Design: A descriptive cross-section design was adopted on the current study .Setting: This study was carried out Hospital of Dermatology, Venereal and leprosy in Dakahelia Governorate. Subjects: A purposive sample was used to this study and compromised of 325. Tool: Two tools were utilized to collect necessary data in this study. Tool I, Structured interview. Tool II, the World Health Organization Quality of Life (WHOQOL) -BREF. Results: The present of study showed that, more than half of leprosy patients $(55.4 \%)$ rated their quality of life as very poor. most of leprosy patients had a poor knowledge (99.7\%) and had negative attitudes toward leprosy. And also there are appositive statically significant relation between four domain of quality of life, age ,and family number. Conclusions: Majority of leprosy patients were not working, low education stander and living in rural area, most of leprosy patients had a poor knowledge and had negative attitudes toward leprosy. Recommendations: contagious training program about leprosy for leprosy patients through visual aids such as posters and clear language booklets to improve their knowledge.
\end{abstract}

Keywords: Leprosy patients , Quality of life 


\section{INTRODUCTION}

Leprosy, also called Hansen disease, chronic infectious disease that affects the skin, the peripheral nerves (nerves outside the brain and spinal cord), and the mucous membranes of the nose, throat, and eyes. It is caused by the leprosy bacillus, Mycobacterium leprae. Destruction of the peripheral nerves by the bacillus leads to a loss of sensation, which, together with progressive tissue degeneration, may result in the extremities' becoming deformed and eroded (Bello et al. , 2013).

Leprosy has been linked to defects in cell-mediated immunity. Milder disease has been associated with human leukocyte antigen HLA-DR3, and more severe disease has been associated with HLA-DQ/DR variants (Blackwell et al., 2009).

Leprosy, also known as Hansen's disease, is a chronic granulomatous disease of the peripheral nerves and superficial tissues that is caused by Mycobacterium leprae, an acidfast bacillus (Vick et al, 2015). leprosy is characterized by a long and variable incubation period that may take up to 5 to 7 years from inoculation to presentation of clinical disease (Weng et al., 2011).

Leprosy occurs more commonly among those living in poverty. Contrary to popular belief, it is not highly contagious(Sengupta, 2016). Leprosy can affect people of all races all around the world. However, it is most common in warm, wet areas in the tropics and subtropics. (Ngan, 2014).

Pretty leprosy is one of the rare severe forms of lepromatous leprosy. (Anand et al., 2014). 2-Type 1 reaction (T1R) in leprosy is common and characterized by increased inflammation in skin lesions or nerve Type 1 reaction (T1R) in leprosy is common and characterized by increased inflammation in skin lesions or nerve ( Walker \& Lockwood, 2008). 3-Tuberculoid leprosy (TT) is characterized by the presence of unique or few small-sized lesions showing well-defined and elevated borders (papules and plaques) (Nunzi\&Noto, 2008).

Borderline leprosy is characterized by numerous, red, irregularly shaped plaques, sensory loss is moderate. (Ngan, 2014). 5- Lepromatous leprosy (LL) (Leonine Facies)is the most severe stage, diffuse skin lesions and high bacterial load. It characterized by diffuse skin infiltration associated with sensory loss in hands. (Salgado \&Barreto, 2012). 
QOL is a multidimensional construct that incorporates the physical, mental, psychological, social and spiritual functioning of the individual and it used to understand the effects of the disease on the patient (Sawafta\& Chen, 2013).

\section{Significant of the study}

The global registered prevalence of leprosy at the beginning of 2015, stood at 211.973cases, and 176176 cases were detected at the end of year (2015) (World Health Organization, 2017). The prevalence of leprosy in Egypt was higher in the year 2011 was, 7368 cases, compared to the number of new cases reported in the same year (4357 cases)(World Health Organization, 2012)2. The overall prevalence of clinical leprosy inrural Egypt was 24.9/10,000(Hegazy et al., 2002). InDakahelia Government prevalence of leprosy 1532 cases were registered(statistical department.2017).Moreover, there is a little knowledge about leprosy patients so the aim of the study was to assess quality of life among leprosy patients.

\section{AIM OF STUDY:}

Assess quality of life among leprosy patients in Dakahlia Government.

\section{Objectives:-}

1- Assess patients' knowledge toward leprosy.

2- Identify leprosy patients' physical quality of life.

3-Identify leprosy patients' psychological quality of life.

4- Identify leprosy patients' social relation quality of life.

5- Identify leprosy patients' environment quality of life.

\section{SUBJECTS AND METHODS:}

\section{Research Design:}

A descriptive cross-section research design was utilized in the present study to achieve the aim of the current study.

\section{Study Setting:}

This study was carried out at Hospital of Dermatology, Venereal and leprosy in Dakahelia Governorate.

\section{Sample Type:}

A purposive sample technique was used to select the required sample. 


\section{Sample Size:}

The sample size was determined according to the following of the equation:

Robert Mason(1999) $n=\frac{M}{\left[\left(S^{2} \times(M-1)\right) \div p q\right]+1}$

$\mathbf{N}=$ sample size

$\mathbf{M}=$ population number (1450)

$\mathbf{S}=$ a percentile of standard normal distribution determined by $95 \%$ confidence level = 1.96divided on the width of the confidence interval $=0.05$

$\mathbf{P}=$ the available percentage

$\mathbf{q}=$ the remain percentage

According to this equation, the estimated sample size was 325 leprosy patients.

\section{TOOLS OF DATA COLLECTION}

To achieve the aim of the proposed study, two tools were utilized to collect data pertinent to the study variables.

\section{TOOL (I): Structured interview:}

It was developed by the researcher based on reviewing related literatures, it includes two parts:

Part (I):It include socio- demographicdata, it contains 11 items this include: age, sex, education,residence, work, type of work, income,family number,number of rooms ,disease duration and medication.

\section{Part(II): patients 'knowledge about leprosy.}

It contained 10 questionsthat addressed for leprosy patients knowledge about leprosy. These included, definition of leprosy, causes, symptoms, mode of transmission, duration of treatment, drugs used in treatment, types of leprosy,type of leprosythat patients suffer,complications, and curable of leprosy. 


\section{Scoring system:-}

The scoring system consists of score (2)was given to completely correct answer, score (1) is given to an incompletely correct answer, and (0) for incorrect answer. These scores have converted into a percentage score. The study group's knowledge is evaluated good if the percent score was $\geq 75.0 \%$ while considered average knowledge if the percent score is $50.0-<75.0 \%$ and poor knowledge if the percent score is $25.0-<50 \%$.

\section{Tool II: The World Health Organization Quality of Life (WHOQOL) -BREF:}

It was designed byWorld Health Organization (2004) to measure the quality of life profile. It is consists of derive four domain scores. Physical, psychological, social relationships and environment There are also two items that are examined separately: question 1 asks about an individual overall perception of quality of life and question 2 asks about an individual general overall perception of their health. The four domain scores denote an individual perception of quality of life in each particular domain. Domain scores are scaled in a positive direction (i.e. very dissatisfied to very satisfied and from not at all to completely scores to 0-100 scale) (i.e higher scores denote higher quality of life).

\section{(II) OPERATIONAL DESIGN}

The operational design included content validity of the tool, pilot study and field work.

\section{Tools validity:}

The tool knowledge of patients toward leprosy It was ascertained by a jury consisting of five experts in community nursing field.

The toolof World Health Organization Quality of Life (WHOQOL), it was translated to Arabic and re- translated to English and ascertained by five experts in the field of community health nursing.

\section{Reliability}

Cronbach alpha coefficient was calculated to assess the reliability of the toolandTest was $95.0 \%$.

\section{Pilot Study:}

The pilot study was carried out on $10 \%$ of the total sample (32 patients) of the study subjects to test the tools before starting the data collection. The purpose of the pilot 
study were to test the clarity applicability and feasibility of the study tools and to estimate the time needed to fill in the tools, it also helped to find out any obstacles and problems that might interfere with data collection.According to the pilot study, certain modification were done and was conducted over a period of one month from the beginning of July 2016 to the end of it.and hence in the pilot study were included from the main study sample.

\section{Result of the pilot study:}

After conducting the pilot study it was found that the sentences of the tools were clear, relevant, but few words have been modified according to the pilot study result. Simple modifications were done as rephrasing question or revoke some question.

\section{Field Work:}

- The researcher selected leprosy patients who fulfilled the criteria from the previously mentioned settings. They were given an opportunity to refuse orto participate.

- The purpose of the study was explained to each patient agreed to participate in the study prior answering the questionnaire sheet then, an oral consent was obtained from them.

- They were assured that the information given would be treated with confidentiality and used for the research purpose only, also assured regarding their right to withdraw from the study at any time without giving any reasons.

- The researcher knew and determined the suitable time to the patients by the managerof Hospital of Dermatology, Venereal and leprosy in Dakahelia Governorate.

- Data were been collected from the selecting setting by the researcher using the constructed tool at the time of the study.

- During data collection interviews each patient\& question of data collection sheet was explained by the researcher to the participants of leprosy patients.

- The study tool was filled by the researcher, and it was distributed and answered within 20-30 minutes then collected.

- The study was conducted from the beginning of August to the end of December 2016. Data was collected through two days per week (Saturday,Wednesday). In every day of data collection, the researcher interviewed with about ten to eleven (9-10) of leprosy patients. 
- The present study consumed 10 months, four months of them for obtaining the official permissions, pilot study and modifications of the tool. The next four months consumed for data collection while, the last two months for data entry and statistical analysis.

\section{(III) ADMINISTRATIVE DESIGN}

An official permission was taken from the dean of the faculty of nursing in Port Said University to the directors of the Hospital of Dermatology, Venereal and leprosy in Dakahelia governorate, to ensure their cooperation and permission after an explanation of purpose and objectives of the study.

\section{Ethical consideration:}

The aim of the study has been explained to directors and patients before asking patients to participate in the study, stressing the confidentiality of the collected data. The researcher emphasized that participation were absolutely voluntary and each student has the right to withdraw from the study at any time with no questions asked as well as confidentiality was assured.

\section{(IV) STATISTICAL DESIGN}

The raw data were coded and transformed into coding sheets. The results were checked. Then, the data were entered into SPSS system files .Version 16.0).Output drafts were checked against the revised coded data for typing and spelling mistakes. Finally, the analysis and interpretation of the data were conducted.

\section{The following statistical measures were used:}

- Descriptive statistics including frequency and distribution were used to describe different characteristics.

- Statistically analyses including: Kruskall Wallis and mann-whitnney tests were used to test the significance of results of qualitative variables.

- A level of $\mathrm{p}<0.05$ was used to determine statistical significance.

\section{RESULTS:}

\section{The main findings of the present study were:}

Table (1): illustrates the general characteristics of the leprotic patients. The table shows that, the age of the leprosy patients ranges from 20 to 74 years with a mean of $(51.79 \pm 9.18)$ year. Concerning gender, the majority of them $(81.2 \%)$ were males, while the minority of them (18.8\%) were females regarding the level of education it was observed that, more than two thirds of leprosy patients $(76.6 \%)$ were illiterate. 


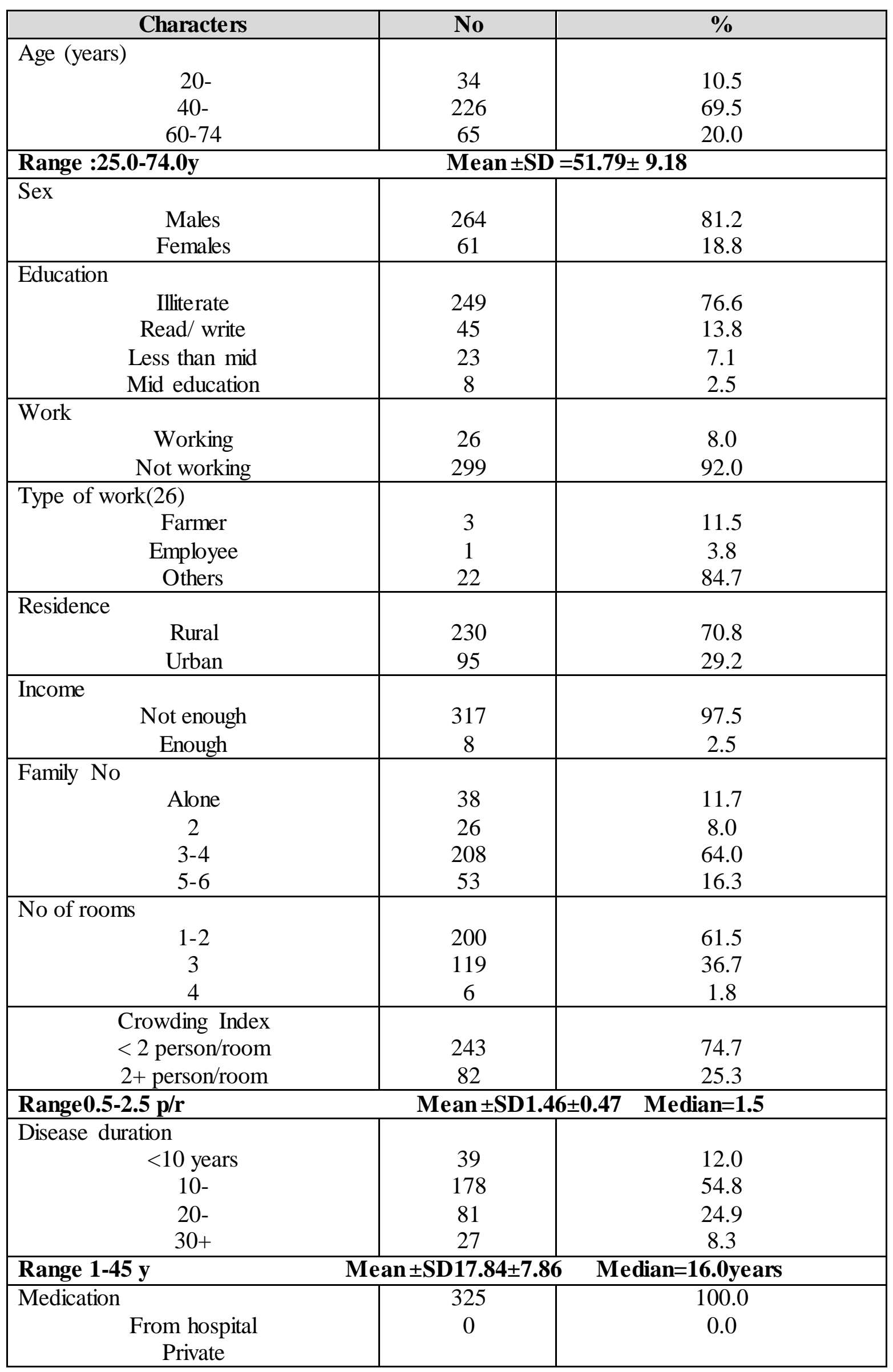


Table (2): reveals distribution of studied leprosy patients towards the questions related to general items of their quality of life. The table indicates that more than half of the leprosy patient $(55.4 \%)$ rated their quality of life as very poor.

\begin{tabular}{|l|l|l|l|l|l|}
\hline Q1 & Very Poor & Poor & $\begin{array}{l}\text { Neither poor } \\
\text { nor good }\end{array}$ & Good & Very good \\
\hline $\begin{array}{l}\text { How would } \\
\text { you are rate } \\
\text { quality of } \\
\text { life? }\end{array}$ & No (\%) & No (\%) & No (\%) & No (\%) & No (\%) \\
\hline Q2 & $\begin{array}{l}\text { Very } \\
\text { dissatisfied }\end{array}$ & Dissatisfied & $\begin{array}{l}\text { Neither } \\
\text { dissatisfied } \\
\text { nor satisfied }\end{array}$ & Satisfied & $\begin{array}{l}\text { Very } \\
\text { satisfied }\end{array}$ \\
\hline $\begin{array}{l}\text { How satisfied } \\
\text { are you with } \\
\text { your health? }\end{array}$ & No(\%) & No (\%) & No (\%) & No (\%) & No (\%) \\
\hline
\end{tabular}

Table (3): demonstrates that, more than half of the study group felt that physical pain prevent them from doing what they need to do very much $(55.4 \%)$ and they need a medical treatment to function in daily life very much equal in percentage. In addition, about one third of the study group a little and not at all had enough energy for everyday life $(32.3 \%$ \& 32.9\%) respectively. The same table demonstrates .the highest percentages of leprosy patients were dissatisfied about sleeping, ability to perform daily living activities, and capacity for work $(59.4 \%, 62.2 \%, \& 62.5 \%)$ respectively.

\begin{tabular}{|c|c|c|c|c|c|}
\hline & Not at all & A little & $\begin{array}{l}\text { Moderate } \\
\text { amount }\end{array}$ & $\begin{array}{l}\text { Very } \\
\text { much }\end{array}$ & $\begin{array}{l}\text { At extreme } \\
\text { amount }\end{array}$ \\
\hline \multirow{2}{*}{$\begin{array}{l}\text { To what extent do you feel } \\
\text { physical pain prevent you from } \\
\text { doing what do you need to do? }\end{array}$} & No (\%) & No (\%) & No (\%) & No (\%) & No (\%) \\
\hline & $8(2.5)$ & $32(9.8)$ & $91(28.0)$ & $180(55.4)$ & $14(4.3)$ \\
\hline \multirow{3}{*}{$\begin{array}{l}\text { How much do you need medical } \\
\text { treatment to function in your } \\
\text { daily life? }\end{array}$} & No (\%) & No (\%) & No (\%) & No (\%) & No (\%) \\
\hline & $1(0.3)$ & $20(6.2)$ & $39(12.0)$ & $180(55.4)$ & $85(26.3)$ \\
\hline & Not at all & A little & Moderately & Mostly & Completely \\
\hline \multirow{3}{*}{$\begin{array}{l}\text { Do you have enough energy for } \\
\text { everyday life? }\end{array}$} & No $(\%)$ & No $(\%)$ & No (\%) & No $(\%)$ & No (\%) \\
\hline & $107(32.9)$ & $105(32.3)$ & $76(23.4)$ & $37(11.4)$ & 0 \\
\hline & Very Poor & Poor & $\begin{array}{l}\text { Neither poor } \\
\text { nor good }\end{array}$ & Good & Very good \\
\hline \multirow{3}{*}{$\begin{array}{l}\text { How well are you able to get } \\
\text { around? }\end{array}$} & No $(\%)$ & No (\%) & No (\%) & No (\%) & No (\%) \\
\hline & $118(36.3)$ & $147(45.2)$ & $59(18.2)$ & $1(0.3)$ & 0 \\
\hline & $\begin{array}{c}\text { Very } \\
\text { dissatisfied }\end{array}$ & Dissatisfied & $\begin{array}{l}\text { Neither } \\
\text { dissatisfied nor } \\
\text { satisfied }\end{array}$ & Satisfied & $\begin{array}{c}\text { Very } \\
\text { satisfied }\end{array}$ \\
\hline \multirow{2}{*}{$\begin{array}{l}\text { How satisfied are you with your } \\
\text { sleep? }\end{array}$} & No $(\%)$ & No (\%) & No $(\%)$ & No (\%) & No (\%) \\
\hline & $77(23.7)$ & 193(59.4) & $53(16.3)$ & $2(0.6)$ & 0 \\
\hline \multirow[t]{2}{*}{$\begin{array}{l}\text { How satisfied are you with your } \\
\text { ability to perform your daily } \\
\text { living activities? }\end{array}$} & No $(\%)$ & No $(\%)$ & No $(\%)$ & No (\%) & No $(\%)$ \\
\hline & $85(26.2)$ & $202(62.2)$ & $32(9.8)$ & $6(1.8)$ & 0 \\
\hline \multirow{2}{*}{$\begin{array}{l}\text { How satisfied are you with } \\
\text { your capacity for work? }\end{array}$} & No (\%) & No (\%) & No (\%) & No (\%) & No (\%) \\
\hline & $97(29.8)$ & $203(62.5)$ & $21(6.5)$ & $4(1.2)$ & 0 \\
\hline
\end{tabular}


Table (4): indicates that, there was a statistical significant association between physical quality of life scores and age, sex, residence, family number, and crowding index $(\mathrm{p}=0.000, \mathrm{p}=0.012, \mathrm{p}=0.000, \mathrm{p}=0.000 \& \mathrm{p}=0.049)$ respectively, while no effect of education, work nature, income, and disease duration.

\begin{tabular}{|c|c|c|c|c|c|}
\hline Characters & No & & hysical S & ore & Significance \\
\hline & & $\begin{array}{l}\text { Min - } \\
\text { Max }\end{array}$ & Median & Mean \pm SD & \\
\hline $\begin{array}{l}\text { Age (years) } \\
20- \\
40- \\
60-74\end{array}$ & $\begin{array}{c}34(10.5) \\
226(69.5) \\
65(20.0)\end{array}$ & $\begin{array}{l}0.0-38.0 \\
0.0-63.0 \\
0.0-56.0\end{array}$ & $\begin{array}{l}13.0 \\
25.0 \\
31.0\end{array}$ & $\begin{array}{c}10.47 \pm 9.50 \\
26.52 \pm 10.91 \\
30.26 \pm 12.33\end{array}$ & $\begin{array}{c}\mathrm{KW}^{*} \\
\chi^{2}=55.272 \\
\mathrm{P} 0.000\end{array}$ \\
\hline $\begin{array}{l}\text { Sex } \\
\text { Males } \\
\text { Females }\end{array}$ & $\begin{array}{c}264(81.2) \\
61(8.8)\end{array}$ & $\begin{array}{l}0.0-63.0 \\
0.0-56.0\end{array}$ & $\begin{array}{l}25.0 \\
31.0\end{array}$ & $\begin{array}{c}24.84 \pm 12.0 \\
28.84 \pm 13.22\end{array}$ & $\begin{array}{c}\mathrm{MW}^{* *} \\
\mathrm{Z}=2.501 \\
\mathrm{P} 0.012\end{array}$ \\
\hline $\begin{array}{l}\text { Education } \\
\text { Illiterate } \\
\text { Read/ write } \\
\text { Less than mid } \\
\text { Mid education }\end{array}$ & $\begin{array}{c}294(76.6) \\
45(13.8) \\
23(7.1) \\
8(2.5)\end{array}$ & $\begin{array}{l}0.0-56.0 \\
0.0-56.0 \\
0.0-63.0 \\
0.0-38.0\end{array}$ & $\begin{array}{l}25.0 \\
25.0 \\
19.0 \\
22.0\end{array}$ & $\begin{array}{l}26.12 \pm 11.54 \\
25.55 \pm 14.46 \\
21.43 \pm 16.01 \\
21.13 \pm 12.98\end{array}$ & $\begin{array}{c}\mathrm{KW}^{*} \\
\chi^{2}=4.681 \\
\mathrm{P} 0.197\end{array}$ \\
\hline $\begin{array}{l}\text { Work } \\
\text { Working } \\
\text { Not working }\end{array}$ & $\begin{array}{c}26(8.0) \\
299(92.0)\end{array}$ & $\begin{array}{l}0.0-56.0 \\
0.0-63.0\end{array}$ & $\begin{array}{l}22.0 \\
25.0\end{array}$ & $\begin{array}{l}21.54 \pm 14.36 \\
25.94 \pm 12.09\end{array}$ & $\begin{array}{c}\mathrm{MW}^{* *} \\
\mathrm{Z}=1.745 \\
\mathrm{P} 0.081\end{array}$ \\
\hline $\begin{array}{l}\text { Residence } \\
\text { rural } \\
\text { urban }\end{array}$ & $\begin{array}{l}230(70.8) \\
95(29.2))\end{array}$ & $\begin{array}{l}0.0-56.0 \\
0.0-63.0\end{array}$ & $\begin{array}{l}25.0 \\
31.0\end{array}$ & $\begin{array}{l}23.91 \pm 12.22 \\
29.66 \pm 16.70\end{array}$ & $\begin{array}{c}\mathrm{MW}^{* *} \\
\mathrm{Z}=3.907 \\
\mathrm{P} 0.000\end{array}$ \\
\hline $\begin{array}{l}\text { Income } \\
\text { Not enough } \\
\text { Enough }\end{array}$ & $\begin{array}{c}317(79.5) \\
8(2.5)\end{array}$ & $\begin{array}{l}0.0-63.0 \\
6.0-44.0\end{array}$ & $\begin{array}{l}25.0 \\
25.0\end{array}$ & $\begin{array}{l}25.62 \pm 12.30 \\
24.25 \pm 13.73\end{array}$ & $\begin{array}{c}\mathrm{MW}^{* *} \\
\mathrm{Z}=0.218 \\
\mathrm{P} 0.828\end{array}$ \\
\hline $\begin{array}{l}\text { Family No } \\
\text { Alone } \\
2 \\
3-4 \\
5-6 \\
\end{array}$ & $\begin{array}{c}38(11.7) \\
26(8.0) \\
208(64.0) \\
53(16.3) \\
\end{array}$ & $\begin{array}{l}6.0-63.0 \\
0.0-50.0 \\
0.0-56.0 \\
0.0-44.0\end{array}$ & $\begin{array}{l}41.0 \\
19.0 \\
25.0 \\
25.0\end{array}$ & $\begin{array}{c}38.87 \pm 11.62 \\
24.92 \pm 13.61 \\
23.67 \pm 11.51 \\
23.92 \pm 9.29 \\
\end{array}$ & $\begin{array}{c}\mathrm{KW}^{*} \\
\chi^{2}=44.491 \\
\mathrm{P} 0.000\end{array}$ \\
\hline $\begin{array}{l}\text { Crowding } \\
\text { Index } \\
<2 \text { person/room } \\
2+\text { person/room }\end{array}$ & $\begin{array}{l}243(74.7) \\
82(25.3)\end{array}$ & $\begin{array}{l}0.0-63.0 \\
0.0-44.0\end{array}$ & $\begin{array}{l}22.0 \\
25.0\end{array}$ & $\begin{array}{l}26.39 \pm 12.84 \\
23.22 \pm 10.32\end{array}$ & $\begin{array}{c}\mathrm{MW}^{* *} \\
\mathrm{Z}=1.969 \\
\text { P } 0.049\end{array}$ \\
\hline $\begin{array}{l}\text { Disease } \\
\text { duration } \\
<10 \text { years } \\
10- \\
20- \\
30+\end{array}$ & $\begin{array}{c}39(12.0) \\
178(54.8) \\
81(24.9) \\
27(8.3)\end{array}$ & $\begin{array}{l}0.0-56.0 \\
0.0-36.0 \\
6.0-44.0 \\
0.0-31.0\end{array}$ & $\begin{array}{l}25.0 \\
25.0 \\
31.0 \\
25.0\end{array}$ & $\begin{array}{c}24.08 \pm 14.21 \\
26.12 \pm 13.79 \\
26.43 \pm 8.48 \\
21.78 \pm 7.59\end{array}$ & $\begin{array}{c}\mathrm{KW}^{*} \\
\chi^{2}=3.933 \\
\mathrm{P} 0.269\end{array}$ \\
\hline
\end{tabular}




\section{DISCUSSION:}

Leprosy is a long-term infection by the bacteria mycobacterium leprea or mycobacterium lepromatosis .Leprosy is spread between people this is thought to occur through cough or contact with fluid from the nose of an infectious patients and commonly among those living in poverty contrary to popular belief it is not highly contagious. (Earla ,2015).

Since leprosy is not very contagious social stigma has been associated with leprosy for much of history which continues to be a barrier to self-reporting and early treatment (WHO,2014)1.

As regarding of general quality of life This finding may be patients' knowledge level is not adequate because of inadequate health teaching and the majority of patients were illiterate, so they can't read articles about leprosy and changing in culture. As regarding of general quality of life the present study findings, the majority of patients rating their quality of life satisfied was very poor and poor .this result in agreement with (Al-Sieni, Al-Layati, \& Al-Abbasi,2013) who were reported, there was study people with leprosy -related disabilities had significantly worse total WHQOL-BREF and lower physical, psychological and environment and individual that leprosy related disabilities affect all aspect of everyday life. This is may be due to the leprosy disease affected in patients as general because of consequences that going on long term on life. As regarding physical quality of life the current study was related that pain occupied a large space of leprosy that majority of them pain preventing doing what they want and hadn't enough energy for everyday life this result in agreement with (Tiwari et al ;2015) revealed that patients with pain had lower quality of life and affects patients in physical health domain and pain affected on a physical needs of patients and also in the present study the majority of the patients show that very dissatisfied to dissatisfied regarding medical need, sleep, daily living activities , and capacity of work this result in agreement with the study of quality of life and its domains in leprosy patients after neurolysis by (Reis et al;2013) reported that $94 \%$ of their sample of leprosy patients with neuropathic pain had their sleep disrupted while the study of assessment of knowledge, attitude and practice towards post exposure prophylaxis for HIV among health care workers in Gondar, North West Ethiopia by (Mathews et al; 2013) indicated the pain in leprosy affected activities and capacity of work. In the same way the study of an assessment of knowledge and attitudes towards leprosy/Hansen's disease amongst healthcare workers in 
Guyana by (Briden\&Muguire , 2014) reported the most affected domain was the physical domain because pain affect specific item of it is domain such as dependence on medicinal substance, medicinal aids pain and discomfort able ;sleep and rest and work capacity. On the same line . This finding due to severe pain and deformity of leprosy patients. As regard relation between physical quality of life domain and sociodemographic noticed by the results of the current study findings, there is statistical significant association between age and residence this study agree with (Geetha et al; 2015)who found a significant relation between age and quality of life among leprosy patients. And also (Msyamboza et al;2013) reported in his study burden of leprosy in Malawi: community camp-based cross- sectional study that there was a significant decrease in the mean score of people affected by leprosy reintegrated in the communities

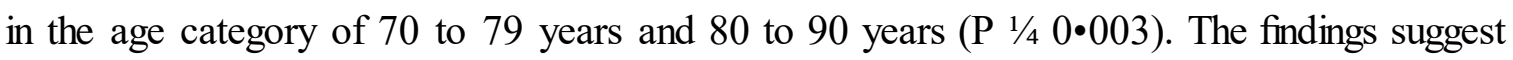
that there is a significant interaction between age and residence on the WHOQOL-BREF mean score in the communities. Results indicate that those aged 70 to 90 years living in the leprosarium had a better score of WHOQOL-BREF than those of the same age band re-integrated in the communities. This means that the elderly affected by leprosy aged more than 70 years in the leprosarium had a better quality of life than those aged more than 70 years who had been re-integrated in their communities. This may be due to younger age in early age and need to build itself so the disease hinders life and lead to low of quality of life.

\section{CONCLUSION:}

The conclusions were made from the results of the present study were:-

Majority of leprosy patients were not working, low education stander and living in rural area,most of leprosy patients had a poor knowledge and had negative attitudes toward leprosy. There were statistically significant in age, sex, residence, family number and crowding index with physical status $(\mathrm{p}<0.005)$ and other statistically significant relation between age,residence, family number, crowding index and disease duration with psychological status $(\mathrm{p}<0.005)$. And also statisticallysignificant relation between social status and age, sex and family number $(\mathrm{p}<0.005)$ in the mean of age and environment domain. Finally other statistically significant relation betweenage, sex,work,family numbers and disease duration with environmental quality of life to patient $(p<0.005)$. 


\section{RECOMMENDATIONS:}

Based on the findings of the present study, the following recommendations are suggested:

1) Improve knowledge of leprosy patients through visual aids such as posters, illustrated pamphlets simple and clear language booklets.

2) Health education to the public has to be strengthened; good attitude towards leprosy patients should be sustained; and leprosy services in district and provincial hospitals improved as a one-step service for leprosy patients.

3) Health education to decrease sham also enhance the group faith from claiming leprosy patients talking neighborhood conviction furthermore discernment for mentality to leprosy patients.

\section{Recommendations for further Research}

A develop programed togain affectation the patients and global episode obligation further should also be dispassionate to dash misconception related to cause and spread of the disease.

\section{REFERENCES}

Bello, A. I., Dengzee, S. A., \& Iyor, F. T. (2013). Health related quality of life amongst people affected by leprosy in South Ghana: a needs assessment.

Blackwell, J.M., Jamieson, S.E., \&Burgner, D. (2009): HLA and infectious diseases. Clin Microbiol Rev; 2(2): 370-85.

Briden, A. N. I. T. A., \& Maguire, E. (2014). An assessment of knowledge and attitudes towards amongst leprosy/Hansen's disease workers in Guyana. Leprosy review, 74(2), 154-162.

Earla, P. (2015): Long lasting disease: Leprosy. J Infect Dis Ther; 3(9):77-87.

Hegazy, A., Abdel-Hamid, I., Ahmed, E., Hammad, S., \&Hawas, S. (2002): Leprosy in a high-prevalence Egyptian village: epidemiology and risk factors. International Journal of Dermatology; 41(10): 681-686. 
Geetha,K., Dhanalakshmi,A.,\&Judie,A.(2015): A study to assess the impact of leprosy on quality of life among leprosy patients' in government rehabilitation homer at Paranur .International Journal of Pharmaceutical and Clinical Research ,7(6),466-468.

Mason, R. D., Lind, D. A., \& Marchal, W. G. (1999). Statistical techniques in business and economics. The Irwin/TheMcGraw-Hill series operations and decision sciences.

Mathews, B., Birhan, W., \&Kinfe, S.(2013): Assessment of knowledge, attitude and practice towards post exposure prophylaxis for HIV among health care workers in Gondar, North West Ethiopia. BMC Public Health; 13: 508-515.

Msyamboza KP, Mawaya LR,\& Kubwalo HW(2013): Burden of leprosy in Malawi: community camp-based cross- sectional study. BMC International Health and Human Rights,; 12 ( 12) 845-850

Ngan, V. (2014): Leprosy .Derm Net. Available at: http://dermnetnz.org/bacterial/leprosy.html

Nunzi, E., \& Noto, S. (2008). Observing the skin: papules and nodules in leprosy. Lepr Rev, 79(118), 678.

Reis, F. J., Cunha, A. J. L. A., Gosling, A. P., Fontana, A. P., \& Gomes, M. K. (2013). Quality of life and its domains in leprosy patients after neurolysis: a study using WHOQOL-BREF. Lepr Rev, 84(2), 119-23.

Salgado, C. G., \& Barreto, J. G. (2012). Leonine Facies: Lepromatous Leprosy. New England Journal of Medicine, 366(15), 1433.

Sawafta, F.J., \& Chen, X.(2013): Quality of life of Chinese heart failure patients and their family caregivers. International Journal of Applied Science and Technology; $3(2): 18-32$.

Sengupta U (2016).Hansen's Disease (Leprosy) Transmission" Journal of Educational Sciences 3(3)15-18. 
Al-Sieni, A. I., Al-Layati, W. Z., \& Al-Abbasi, F. A. (2013). Temporal adverse effects in leprosy Saudi patients receiving multidrug therapy. Clin Exp Pharmacol, 4, 1.

Statistical department(2017): Hospital of Dermatology ,Venereal and leprosy in Dakahelia Governorate.

Tiwari, M., Ranabhat, S., \& Maharjan, S. (2015). Clinico-histopathological correlation of leprosy: A retrospective study of skin biopsy specimens in Chitwan Medical College. International Journal of Medical Science Research and Practice, 2(1), 8-11.

Vick, G.L., Tillman, E.A., \&Fiala, K.H. (2015): Leprosy in a Texan. Proc; 28(2): $231-232$.

Weng, X., Vander Heiden, J., Xing, Y., Liu, J., \& Vissa, V. (2011). Transmission of leprosy in Qiubei County, Yunnan, China: insights from an 8-year molecular epidemiology investigation. Infection, Genetics and Evolution, 11(2), 363-374.

World Health Organization (2012)2: Program managers' meeting on leprosy elimination, Cairo, Egypt. Available at:

http://apps.who.int/iris/bitstream/10665/116159/1/IC_Meet_Rep_201214816_EN.p $\underline{\text { df?ua }=1}$

World Health Organization (2014) 1 : symptoms of leprosy Available at: https://www. who.com/health/leprosy\#s ymptoms

World Health Organization (2014)z: symptoms of leprosy Available at: https://www. who.com/health/lepros y\#dignosis

World Health Organization (2017): Prevalence of leprosy. Available at: http://www.who.int/ mediace Feb 2017. 


\section{جودة الحياة بين مرضى الجذام}

نسمه محمد فهيم ، جهاد محمد ابو المعاطى، نجلاء ابر اهيم غيدة ، عبد الناصر رمضان

\section{الخلاصة}

الخلفية: سبب الجذام هو البكتريا المسببه له وينتشر بين أولئك الذين يعيشون في فقر. يرتبط الجذام فى مختلف

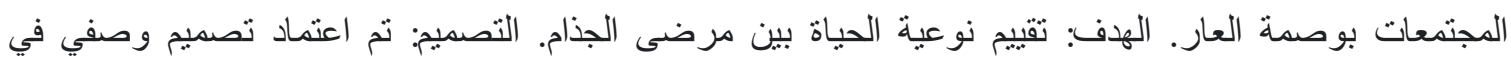
الدراسة الحالبة المكان: أجريت هذه الدراسة بمستشفى الأمراض الجلدية والتناسلية والجذام بمحافظة الدقهلية. العينة:

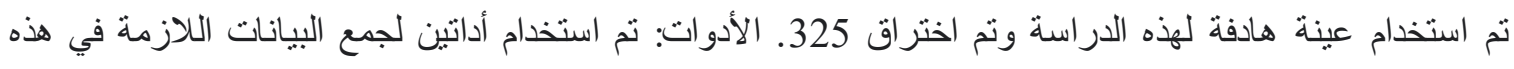
الدراسة. الأداة الأولى ، مقابلة منظمة. الأداة الثانية ، منظمة الصحة العالمية جودة الحياة WHOQOL) - BREF). النتائج: أظهرت الدراسة الحالية أن أكثر من نصف مرضى الجذام (55.4\%) صنفوا نوعية حياتهم على أنها سيئة للغاية. كان لدى معظم مرضى الجذام معرفة ضعيفة (99.7\%) ولديهم سلوك سلبي تجاه الجذام. الاستنتاجات: الغالبية العظمى من مرضى الجذام لا يعملون ، ولديهم مستوى تعليمي منخفض ويعيشون في المناطق الريفية ، ومعظم

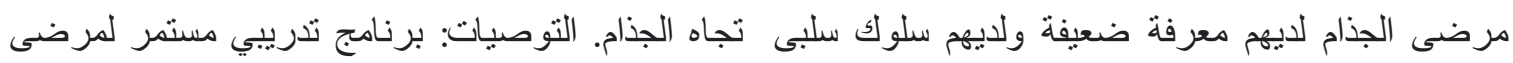
الجذام حول مرض الجذام من خلال الوسائل البصرية مثل الملصقات وكتيبات اللغة الواضحة لتحسين معرفتهم.

$$
\text { الكلمات المرشدة : مرضى الجذام ، نوعية الحياة }
$$

